\title{
Rising Powers and Peacebuilding: India's Role in Afghanistan
}

\author{
Shakti Sinha
}

\section{INTRODUCTION}

The gradual shift in the economic and political gravity towards the Global South, particularly the Indo-Pacific, is also reflected in the increased role of these rising powers in stabilising countries emerging from conflict. While in terms of amounts of financial resources deployed by them, aside from China whose assistance figures are ambiguous, may not appear very large, the question to be addressed is whether these new actors have brought a different approach to issues of peacebuilding, more especially with reference to projects being demand-driven and owned by recipient societies.

China, and to a lesser extent India, is accused of tailoring its assistance to take advantages of natural resources available in African countries. This criticism is further buttressed by the conviction that such flows from 'emerging donors might increase the recipients' debt levels, ignore environmental and social impacts, and focus on extracting resources ... resulting in an erosion of the progress that has been made in the traditional aid community in these areas' (Dornsife 2013). On the other hand, these rising powers do not see themselves as donors but as development partners;

S. Sinha $(\varangle)$

Nehru Memorial Museum and Library, New Delhi, India

(C) The Author(s) 2017

C.T. Call, C. de Coning (eds.), Rising Powers and

Peacebuilding, Rethinking Peace and Conflict Studies, DOI 10.1007/978-3-319-60621-7_7 
their assistance may be tied but has no policy conditionalities attached to them, are demand-driven and are premised on non-interference in the affairs of recipient countries (Dornsife 2013; Roopanaraine 2013).

Going deeper, what are the strategic goals and interests of these rising powers? What motivates them to extend assistance to other, developing countries? And are these motivations different from that of traditional donors? Do they differentiate between 'normal' development and peacebuilding? Does peacebuilding imply a sequenced approach with securing peace as the first priority, followed by state-building and then development? And are the projects taken by these rising powers perceived to be successful by the governments and people of the recipient countries?

The emerging powers generally, and India specifically, because they see themselves as partners and not donors, are driven by a different set of motivations. Having suffered from colonialism which involved not just pauperisation but also loss of political agency, the emerging powers focused on the need to become economically self-sustaining, though in the age of globalisation this is a more nuanced view. Sharing experience and technology was seen as the best way to overcome the lack of capital. A primacy to national sovereignty and hence non-interference in the internal affairs of each other meant that the concept of conditionality was not accepted though tied aid was-both to overcome the need to import from the developed countries and in the spirit of mutual gain. Like traditional donors, political and strategic considerations cannot be ignored, even if the approach is context-specific.

A critical look at India's role in Afghanistan would be used to examine these sets of questions dealing with the role, innovations and effectiveness of the rising powers in building peace. India has been the fifth largest bilateral donor in Afghanistan, and the largest outside the developed countries. This offers a unique opportunity to study the performance of a non-traditional donor in a conflict-affected country; it can be no one's case anymore that Afghanistan is a country that is 'actually' emerging from conflict, and yet the country over the past 14 years has made tremendous strides in many fields, for example, school education, health coverage, communications, role of civil society, growth of a free media and holding regular elections including a peaceful transition of power.

The format of the chapter is that, after a brief introductory section, the second section will trace India's emergence as a donor, examining its driving principles and the evolution of its instruments. This too needs substantial elaboration since there is general lack of knowledge, as well as 
misconceptions, about the size of India's development assistance as well as misgivings about India's presence in this field, hitherto the preserve of donors from developed countries. The third section will look at India's role in Afghanistan, its development initiatives, the strategic factors driving its Afghan policy and will briefly compare India's development interventions with that of the United States. The fourth section will look at how India's development partnership is perceived in Afghanistan and whether it contributes to peacebuilding, or is divisive and exclusionary. The concluding section will attempt to draw lessons from India's development engagement with Afghanistan with a view to strengthening peacebuilding efforts in countries emerging from conflict.

\section{INDIA AS DONOR ${ }^{1}$}

Contrary to general perception, bolstered by the fact that India is the largest borrower from the World Bank (WB) and the Asian Development Bank (ADB), India has been involved in bilateral, and multilateral, development partnership since the early days of its independence. In 1949, the newly independent Burma (now Myanmar) faced a serious crisis in its balance of payment. Prime Minister Nehru organised a meeting of Commonwealth countries that raised six million pound sterling on concessional terms for Burma; India's own contribution was one million pounds. In addition, India extended a bilateral special concessional loan of Rupees five million to Burma to buy rice from India. ${ }^{2}$

India was an active participant in the setting up of the Colombo Plan for Cooperative Economic Development in South and Southeast Asia during 1950-51. Though the Colombo Plan was initially designed within the traditional developed country donor-developing country recipient framework, it soon evolved as the pioneer instrument of South-South cooperation centred on 'technical cooperation and sharing of development experience.' During these early years, India extended technical cooperation partnership under Colombo Plan as well as extended financial assistance to its neighbours, for example, 'loans of around 200 million rupees to Myanmar and 100 million rupees to Nepal' in the 1950s (Chanana 2009).

From the outset, India's approach was quite different from that of the traditional donors (developed countries). For India the driving force was development partnership, and it did not see itself as a donor even when it extended concessional loans, advances in Indian budgetary parlance. India saw itself 
as a part, albeit leading one, of the group of developing countries emerging from decolonisation with under-developed economies. The common history of colonisation and emphasis on economic growth bound these countries together. Anti-colonialism meant that egalitarianism and partnership, not aid, should be the focus. What further made India adopt its own path was the Cold War that threatened to divide the world into two, opposing camps. Loath to lose their independence and freedom of action that they interpreted joining either camp meant, India and the others sought their space. The adoption of Panchsheel, or five points, at the Bandung Afro-Asian summit in 1955 was the result, to be followed in 1961 with the launch of the nonaligned movement. Panchsheel committed these countries to respect each others' sovereignty and not interfere in the internal affairs of other countries.

While recognising the political cause of their under-development (colonialism), in the circumstances India felt it necessary to work with its partners on addressing the economic cause of such under-development through technical cooperation and the sharing of experiences. The driving principles of India's development partnership with other developing countries were expanded to include egalitarianism, country ownership, demand-driven and lack of conditionalities (even where there was tied financing). The latter is significant as mutual respect for sovereignty ruled out imposing any conditions as lenders do. However, the lack of hard currency and desire for self-sufficiency meant that tying aid to purchases from lending country was accepted. Separately this refusal to join either camp enabled India and others to access financial and technical assistance from both camps and from multilaterals.

India did not set up a dedicated agency for external development partnership; instead it was run and coordinated by the Ministry of External Affairs (MEA) which drew on expertise of the relevant line ministries. India formalised its technical assistance efforts by establishing the India Technical and Economic Cooperation programme (ITEC), again located in MEA. ITEC has six main channels:

1. Training of workers from state-owned enterprises, bureaucrats and policy makers nominated by the partner countries;

2. Feasibility and consultancy services related to specific development projects;

3. The sending of Indian experts to the requesting country;

4. Study tours in India for individuals and groups suggested by partner countries; 
5. Donation of hardware to partner countries; and

6. Humanitarian aid for disaster relief (Indian Technical and Economic Cooperation 2013).

For government of India, ITEC was about partnership and learning from each other, quite different from traditional aid. To quote MEA (2012), ITEC's basic proposition is that '...cooperative efforts of the developing countries were as important as assistance from developed countries and international organizations.' The training component has grown very substantially, and in 2012, it covered 200 different training programmes, of varying durations, at forty training institutions with a total of 5000 training slots (Ministry of External Affairs 2012) ITEC Program has evolved and grown over the years and MEA (2012) reports that ITEC and its sister programme, Special Commonwealth African Assistance Programme (SCAAP) has covered 161 countries in Asia, Africa, East Europe, Latin America, Caribbean as well as Pacific and Small Island countries, and is funded by government of India. It is estimated that by 2010 , there were 'more than 40,000 alumni of the ITEC program around the world' (Ramachandran 2010).

India's development partnership programmes in general, including ITEC, are dollar-for-dollar of much greater value since these are overwhelmingly incurred within India and its developing partner countries adjusting for purchasing power parity. In other words, India's external development budget of US\$1.3 billion for 2013-14 would actually translate into effectively 4/5 times larger amount for a developed donor country. ${ }^{3}$

India's development assistance has also been increasing at a reasonably fast pace, particularly since 2000, 'increasing seven-fold between 2000 and 2014. In 2014, Indian development assistance stands at about $\$ 1.3$ billion' (ICRC 2014). This amount may be a slight underestimation as there are other items not fully caught in the budget documents. ITEC is the single largest component, US\$589 million out of this amount. Figure 7.1 tracks the growth in India's development assistance in recent years. The Indian government also makes sizeable contributions to multilateral organisations, including the World Food programme, U.N. Development Program and the World Health Organization.

In fact, this tripling over five years is unprecedented, but even at the lower 2012-13 levels, India's development assistance budget 'was comparable to Austria's foreign aid budget for the same year and higher 


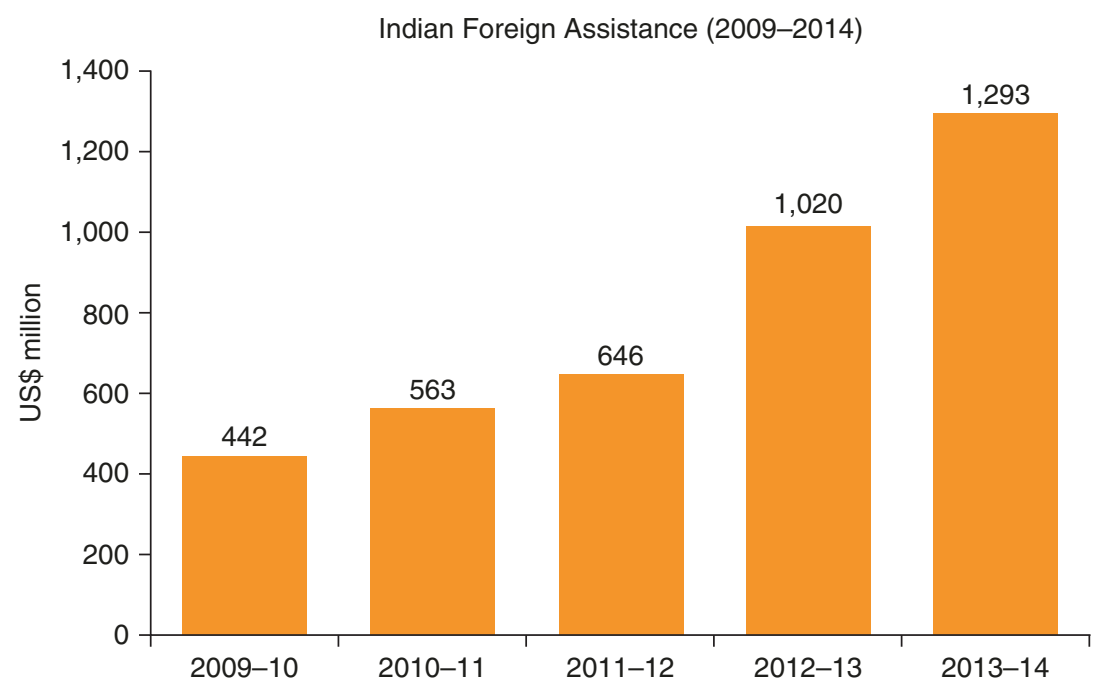

Fig. 7.1 India's development assistance, 2009-2014 Source: Indian Government Note: Excludes line of credit

than the foreign assistance of four of the 23 DAC countries in 2011' (OECD 2012). India's development assistance budget for the year 2015-16 includes a grant element of US\$878 million and US\$180 million earmarked for capacity development (including formal university education in India). There is also a target for extending Letters of Credit (LOCs), US\$2 billion for Africa and US\$500 million for other countries. ${ }^{4}$

Earlier, Indian financial assistance was limited to its immediate neighbourhood but that has since changed, though the former still dominates the flow of funds. In fact, but for developments in Afghanistan, discussed later, and the opening up of Myanmar which made these two countries receive larger and larger amounts of assistance, the share of the neighbourhood would have been considerably less. Myanmar received US $\$ 83$ million in 2013-14, a steep jump from just US\$10 million four years earlier. Significantly, India's aid to Africa has grown at a compound annual growth rate of $22 \%$ over the past ten years (Ramachandran 2010). The top three aid recipients of India's development cooperation are Bhutan (49\%), Afghanistan (9\%) and Nepal (6\%). ${ }^{5}$ 
Realising that the government would be unable to meet from its budget the increased call from its development partners for assistance, India shifted gears over the years 2003-4, spanning two different governments. First, India would be discontinuing the system of offering concessional loans, learning from the HPIC experience where it had to write off advances to Guyana and others, it shifted to outright grants, and also introduced a new instrument, LOCs administered by India's Exim Bank with government picking up a major part of the interest charges, allowing partner countries to pick up highly concessional loans for investments in areas of their choice. This has allowed India to expand its development partnership portfolio considerably without a concomitant charge on its budget, with government's own commitment limited to the interest subvention charges. Exim Bank raises its capital from international bond markets since it needs hard currency for its borrowers. LOCs are tied instruments and as a rule, a minimum of $75 \%$ of goods and services procured under the LOC (with a relaxation of up to $10 \%$ ) must be sourced from Indian companies. However, there is a very substantial grant element, varying from $56.4 \%$ for HPICs, $37.3 \%$ for low-income countries/LDCs and $34.4 \%$ for middle income countries (Arora and Mullen 2017).

The process starts with request received from borrower countries for specific projects. MEA's Standing Committee decides whether to move ahead, and if so, the amount of exposure and recommends the case to the finance ministry. The finance ministry checks availability of budgetary resources and finalises the terms and conditions, based on the borrowing country's income classification. The LOC is operated through EXIM bank, but the procurement process followed is that of the borrowing country. There is no oversight of this by India at all, respecting their sovereignty.

LOCs have become extremely popular and high-level diplomatic visit to such partner countries most often result in announcement of new/ enhanced LOCs. Exim Bank has now in place 226 Lines of Credit, covering 63 countries in Africa, Asia, Latin America, Oceania and the CIS, with credit commitments of US\$16.9 billion; the total amount of contract approvals is US\$7.18 billion, and amount disbursed, US\$5.77 billion (Mathew 2015). Annex I has an illustrative listing of projects.

Doubts have been raised whether these credits should even be thought of as development assistance since LOCs are seen to be promoting the exports of Indian goods and services. However, the level of tied credit, at $75 \%$ of these loans is 'comparable to the de facto tied aid given for example by the US Agency for International Development. Also, the Organization 
for Economic Cooperation and Development (OECD) guidelines on what is to be considered as 'soft loans' categorises such concessional Government of India-backed and Exim-bank distributed LOCs as development assistance. ${ }^{6}$

Africa has become the largest user of Indian LOCs, $52 \%$ of actual disbursals and $45 \%$ of amount committed (Mathew 2015). At the recent India-Africa summit (Oct 26-30, 2015), attended by 41 heads of State/ government out of 54, 'India promised $\$ 10$ billion in new credit and $\$ 600$ million in grant aid to African countries, over five years' (Gupta 2015). India-Africa Development Fund would get an infusion of $\$ 100$ million and India-Africa Health Fund of $\$ 10$ million. The grant would also include 50,000 scholarships in India over the next five years.

Utilising its strength in the IT and IT enabled services (ITES) sector, India would spend a total US\$125 million in setting up the Pan-African e-Network project. It is meant to assist Africa in capacity building by way of imparting quality education to 10,000 students in Africa over a five-year period in various disciplines from some of the best Indian Universities/ Educational Institutions. Besides, this would provide Tele-Medicine services by way of on line medical consultation to the medical practitioners at the Patient End Location in Africa by Indian Medical specialists in various disciplines/specialties. India would cover the cost of supply, installation, testing and commissioning of hardware and software, end-to-end connectivity, satellite bandwidth, O\&M support, and providing the teleeducation and tele-medicine services to 53 African countries for five years.

Forty seven countries have signed up for it. The first phase of the PanAfrican e-Network Project, inaugurated in February 2009, covered 11 countries, namely Benin, Burkina Faso, Gabon, The Gambia, Ghana, Ethiopia, Mauritius, Nigeria, Rwanda, Senegal and Seychelles. The twelve countries launched in 2010 included Botswana, Burundi, Cote d'Ivoire, Djibouti, Egypt, Eritrea, Libya, Malawi, Mozambique, Somalia, Uganda and Zambia.

Regular Tele-Medicine and Tele-Education services have already been started on this network. The Tele-Medicine consultations are regularly being conducted from Super-Specialty Hospitals from India to the African countries on need basis. In addition, regular Continued Medical Education (CME) sessions have started (2009) from 11 Indian SuperSpecialty Hospitals. Regarding Tele-Education services from India, more than 2000 students from Africa have enrolled in five different top-ranking universities in India in various disciplines (Pan-African 2016). India has 
also contributed US\$200 million to NEPAD and is involved in other African-led initiatives.

India's guiding principles, though not formally articulated at one place, is reflected in its approach to development partnership generally. That India's development assistance flows primarily to countries in its neighbourhood should not be a surprise. The subcontinent continues to have the largest numbers of poor people in the world, though not in percentage terms. State formation in many of these countries, or parts within, is still challenged by insurgencies, terrorist violence and weak capacities. As India seeks to emerge as a global power, its own economic achievements and military capability would not compensate for any disarray or state failure in its immediate neighbourhood. Therefore, in addition to seeing others as similarly placed on account of historical reasons and consequently as partners in economic development, India has to sufficiently invest in its neighbourhood to ensure that they too are able to grow economically. This is seen as an important factor in successful State-building. Politically, India cannot be seen to be located in a troubled region. This adds strength to India's basic ethical approach to development partnership. An analysis of Indian development assistance to Afghanistan will show whether or not it is driven by these general principles.

\section{India's Development Partnership with Afghanistan}

India's Prime Minister Narendra Modi was in Kabul on December 25, 2015, to jointly inaugurate with Afghan President Ashraf Ghani the parliament building built by the Indian government. His visit was a big hit in the Afghan media, especially the social media. The government of Afghanistan decided to name one of the blocks of the building after former Indian Prime Minister Atal Bihari Vajpayee, who had offered to build this powerful symbol of democracy as a sign of Afghanistan-India friendship and partnership. It was in his time that India re-engaged with Afghanistan in the aftermath of the US intervention that dislodged the Taliban in late 2001. The pace of engagement accelerated almost immediately, and despite fatal attacks on Indian targets including diplomats, development staff and projects, has maintained its momentum.

That India has emerged as major development partner, arguably the fifth largest bilateral donor over the 14-year period, to Afghanistan should not have come as a surprise to analysts who have worked on Afghanistan 


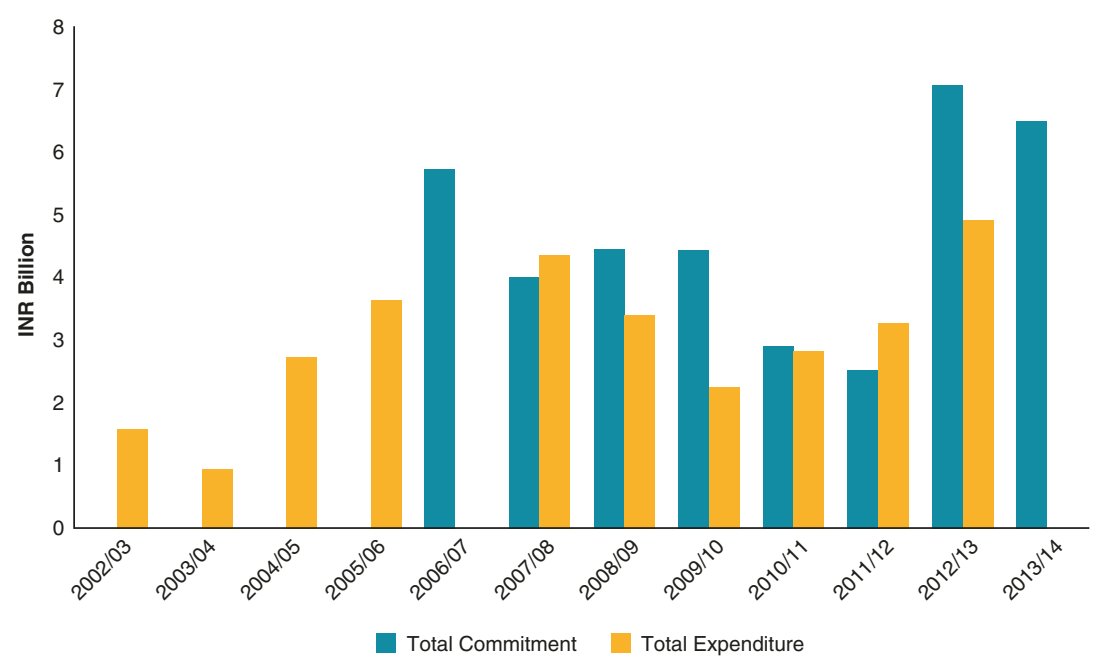

Fig. 7.2 India's development cooperation with Afghanistan: commitments and expenditures, 2002/03-2013/14

Source: Rani Mullen.2014

"IDCR Report: The State of Indian Development Cooperation."

New Delhi: Indian Development Cooperation Research, (Spring)

on the ground. India's development partnership with Afghanistan goes back to the 1950s, and till transit trade through Pakistan was not an issue, was Afghanistan's largest export market for dry fruits. The civil war (1992-96) and subsequent Taliban rule caused a break, though India did extend humanitarian assistance through UN agencies (Mullen 2013) (Fig. 7.2).

India's total commitment for the reconstruction of Afghanistan is US\$2 billion, with more than half disbursed. It has funded/co-funded three very important infrastructure projects, the construction of the $218 \mathrm{~km}$ road from Delaram to Zaranj which gives Afghanistan access to an alternate port, Chahbahar in Iran; it has reconstructed and expanded the Salma Dam which would produce $42 \mathrm{MW}$ of power and irrigate 75,000 hectares of land when fully commissioned by mid-2016; it has co-funded and built transmission towers over the Hindu Kush as part of the Northern Electric Power System (NEPS) that has brought electricity to Kabul and other areas. Some of the key Indian projects are the following: 
- Food assistance to primary school children and construction and rehabilitation of schools (\$321 million disbursed),

- Supply of 250,000 tonnes of wheat,

- Construction of a power line from Pul-i-Khumri to Kabul (\$120 million),

- Annual scholarships to study in India-higher education (initially 500 per year, increased to 675 and then to 1000 ),

- Construction of Delaram-Zaranj road (\$150 million),

- Construction of the Salma Dam Power Project (US\$200 million),

- Construction of the parliament building (\$27 million disbursed; budget $\$ 178$ million), and

- Small Development Projects, initially in the South East, and then extended all over the country.

(Annex II has a comprehensive listing of all Indian development and humanitarian initiatives in Afghanistan.)

It would be useful to look at a few of these initiatives to better understand what India brings, and does not bring, to the table of State-building/ peacebuilding before comparing the Indian approach with that of traditional donors.

India's biggest humanitarian intervention in Afghanistan, supply of 1 million tonnes of wheat in the form of High Energy Biscuits (HEB) distributed to 2 million school children across Afghanistan, also has a strong development impact. Midday meals are shown to be strong motivational factors in increasing enrolment. The World Food Program (WFP), a UN agency is the implementing partner. This supply to Afghanistan was done despite the logistical hurdles posed by Pakistan which had to be overcome. Similar hurdles had to be overcome to deliver 250,000 tonnes of wheat as humanitarian assistance, by technically making delivery to Afghanistan at an Indian port, so that it could travel overland from the Pakistani port of Karachi to Afghanistan.

While the reconstruction and renovation, and subsequent further upgradation of Afghanistan's only children hospital, the Indira Gandhi Institute of Child Health, initially built with Indian assistance about 4 decades back, was a visible intervention in the health sector, what earned the Indian government considerable goodwill all over the country was the stationing of Indian medical missions in cities of Kabul, Jalalabad, Kandahar, Mazar and Herat. However, after attacks on Indian doctors in Kabul leading to fatalities, most had to be shut down. In the decade 
that they operated, they treated hundreds of thousands of patients every year. India is also involved in upgrading medical training and diagnostics facilities. India also accepted the Afghan request to support the Afghan Red Crescent Society (ARCS) to treat Afghan children suffering from Congenital Heart Disease (CHD). Financial assistance of US\$5 million would be given to ARCS over a period of five years beginning 2015, with the first tranche of US\$1 million already released. Financial assistance provided by India will be utilised for the ongoing treatment by ARCS of Afghan Children at Artemis, Max and Fortis Hospitals in New Delhi. These hospitals have also offered special concessional rates for treatment of these children.

In order to increase the 'visual' presence of the government all over Afghanistan, India supported the expansion of the national TV network by providing uplink from Kabul and downlink in all the 34 provincial capitals, a force multiplier for national integration. Similar consideration drove the upgradation of telephone exchanges in 11 provinces.

Recognising that the Afghan government's lack of capacity could seriously constrain its ability to deliver services to its citizens, a key requirement for building peace, India initially offered 500 short-term training annually slots under ITEC, a figure since increased to 675 . At the request of President Karzai for deployment of Indian civil servants as mentors in Afghan ministries, India tied up with UNDP's Capacity for Afghan Public Administration (CAP) programme and deputed 30 Indian civil servants who were placed in different ministries. This was a rare occasion where government of India partnered with another bilateral/multilateral agency in the actual implementation of any development partnership programme; in this case, there were other bilateral funding programme too. This was continued when CAP was modified and became the National Institutional Building programme.

However, capacity building exercises like training and deputing experts as mentors have their limitations. Afghanistan, as a war ravaged country has serious issues with higher education. India, initially offered 500 annual long-term university scholarships for undergraduate and post graduate degrees. This was increased to 675 scholarships in 2009, and to 1000 in 2012-13. And since 2014, 20 of these scholarships are also offered for pursuing $\mathrm{PhD}$ programmes in different subjects. The entire selection process is done by the Afghan government, in line with India's policy of no conditionality. It has been estimated that since 2001, 'more than 10,000 Afghan students have studied in India on ICCR scholarships, with some 
7,000 returning home armed with an education and technical skills, which they are using to drive Afghanistan's stabilization and development.' In addition, 'some 8,000 Afghan students are pursuing self-financed degrees in different fields across India' (Haidari 2015). During his recent visit, Prime Minister Modi announced 500 long-term scholarships for children of security personnel who have lost their lives on duty.

India has also accepted the Afghan government's request to set up a full-fledged agriculture university at Kandahar, a priority for a country where the majority of their labour force is in agriculture, but where due to war, productivity levels are a fraction of what they were pre-1979. Separately, India has made available 614 Agriculture scholarships (BSc, $\mathrm{MSc}$ and $\mathrm{PhD})$. India has also involved its private sector for running vocational training in Kabul, and funded a reputed Indian NGO, Self Employed Women's Association (SEWA) to train 1000 Afghan women in different skills and vocations.

After many stops and starts caused by insecurity and supply bottlenecks, the Indian assisted reconstruction of the Salma dam in Chishti district of Herat province is almost completely commissioned. The dam work and its supply lines were frequently attacked, allegedly at Iran's instance as the power generated by the dam (42 MW) would eliminate Herat's dependence on Iranian supply, as well as by the Taliban (Plot to 2013). At the height of the construction work, there were more than 2000 workers in three shifts, including around 700 Indians. ${ }^{7}$ The total cost of the reconstruction is US\$200 million.

As referred to earlier, India partnered with other bilateral and multilateral donors to bring electricity to Kabul, and many other areas in planning and executing NEPS. This is one of the largest, and definitely the most technologically challenging infrastructure projects ever undertaken in Afghanistan. Besides India, the other partners were the ADB, the United States, Germany, Japan, WB and Islamic Development Bank, a rare instance of so many internationals working in a coordinated manner led by the government of Afghanistan. Over four years, more than 1300 massive pylons were erected to hold transmission lines stretching from the Uzbekistan border to Kabul. The most difficult stretch was over the perennially snow-bound, avalanche-prone Hindu Kush Mountains, towering more than 3800 metres above sea level, was planned and executed by India. Further, an Indian company was the common contractor installing the transmission towers and lines. To add to the complication, the company manufactured most of its materials in India, but due to transit issues, 
the entire material 'had to be shipped from India to Iran, and then driven through Turkmenistan, into Uzbekistan, and finally into Afghanistan at Hairatan, in the north' (Asian Development Bank 2009). India has also set up three substations and is setting up one more. India's share of the project cost is US\$120 million.

India was able to demonstrate both its technical expertise as well as the ability to deal with, and work together, with multilateral agencies and bilateral agencies notorious for working alone. The project not only earned the government of Afghanistan much goodwill by providing electricity to upward of 4 million people but suddenly improved their quality of life, a huge gain for government's credibility. Paradoxically, though USID was an integral part of NEPS, it separately executed many redundant (in view of NEPS) and non-viable power projects including generating stations that had no fuel linkage or would produce expensive power (McCloskey et al. 2015).

In a rare departure from its practice of directly executing its projects, though taken up at the request of the host government, India has partnered with the government of Afghanistan (Ministry of Economy) in implementing the community-based Small Development Projects (SDP). It would also be useful to compare the SDP with Afghanistan government's flagship National Solidarity Program (NSP), which is also community-based.

The SDP was launched in 2006 initially covering seven insecure, underdeveloped border provinces in 2006 , with a view to allowing local communities to invest in their priority needs and in the process better connecting with the Afghan government. ${ }^{8}$ It has since been expanded to all provinces. Government of India initially allocated US\$10 million in phase one, which was supplemented by US\$20 million in phase two. The third phase signed in November 2012 when President Karzai visited India substantially hiked the allocation to US\$100 million, to be utilised by 2016. SDP's priority is to target the most vulnerable but as these are mostly in insecure areas, implementation becomes an issue. The Ministry of Economy (MoE) is the nodal ministry at the national level and its provincial directorates act as nodal points in their respective provinces. The steering committee has representatives from all concerned line ministries as well as the President's office. Specific proposals from communities are endorsed by the Governor and the Provincial Development Council (PDC) and sent to the MoE, which in turn then sends them for vetting to the concerned line ministries, on whose budgets these proposals are borne. Till the time of writing, the Embassy of India had approved 124 proposals, with another 185 proposals 
in different stages in the pipeline. Some of these approved projects have been completed, while others are in different stages of implementation, which is difficult in insecure areas. The health sector dominates with 67 approved projects followed by small, rural development projects (21) and education (17).

Review meetings are held every two weeks and the Council of Ministers is briefed every two months. Based on difficulties faced in implementation, more powers are being given to provincial governors. Presently all procurement decisions are taken by the line ministries and often small mistakes by provincial staff leads proposals being returned for rectifications or fresh processing. MoE is working on improving capacities at local/ provincial level. There is a high local ownership from the community up to the ministers' level. The Afghan government convened a national conference on SDPs in end-2012, attended by 400 participants from across the country, representing civil society, provinces, ministries and so on. The conference laid down the criteria for allocation of funds to provinces keeping in mind the need for balanced growth. The intensive consultative nature of SDP policy formulation and implementation does slow down the process but ensures ownership.

It is worth comparing the SDP to another flagship project of the government, the National Solidarity Program (NSP). )The latter was far bigger, comprehensive in its coverage and in operation for much longer than the SDP. The NSP is a community-based recovery programme created to help in the recovery from decades of conflict, initially through rebuilding rural infrastructure, inspired by the success of Indonesia's Kecamatan Development Program. The actual choice of the project in NSP is left to the community. A community development cluster (CDCs) of around 25 households is established through secret ballot (mixed and single sex) by the facilitating partner (FP), often an NGO. The Government releases block grants to each CDC whose representatives in discussion with their facilitating/implementing partners chooses the specific intervention that is of the highest priority to them. NSP has since covered most of the country and is funded from the general development budget of the country, which in turn receives budgetary support from donors, both multilateral and bilateral. Within the government, the Ministry of Rural Rehabilitation (MRRD) runs the programme. The programme was considered very successful as it contributed to improving rural connectivity and agricultural productivity. MRRD's capacity was also strengthened, and it is regarded one of the star performers of the government. 
Both the NSP and the SDP have their strengths and weaknesses. While NSP is quite participative at the community level, and creates the basic units of democratic choice, though doubts have been expressed about it in practice in different parts of the country, it operates outside the government system. The facilitating/implementing partner gets the credit, not the government as a whole. Its biggest lacuna is the complete absence of ownership outside MRRD, quite unlike SDP. At the same time, NSP has created considerable local, economic assets that are very useful to the community. However, leading from this, its second basic problem is inability to scale up and create projects that bring about sustainable, favourable economic outcomes. Third, what happens to the CDC once the project is over or when the NSP winds down? The resulting frustration could produce cynicism and reversion to more atomised behaviour patterns.

The SDP could do well to replicate CDC-like consultative mechanism. It would also do well to look at additional resources, including by diverting from non-productive programmes and by attracting other donors. Better tracking would improve accountability and lead to better outcomes.

Both the SDP and the NSP emblemise a different approach to peacebuilding and development than that exhibited by many traditional donors in Afghanistan. Reflecting the belief that 'State-building and peacebuilding are primarily internal processes,' (DFID 2010) then-finance minister Ashraf Ghani 'demanded that assistance was to be channelled through the ministries, and aligned with national plans and priorities' (Strand 2014). Many donors including the USAID, Japan and most UN agencies, preferred to execute projects themselves, often without even coordination with the government. The international military in particular with their Provincial Reconstruction Teams (PRTs) and the Commanders' Emergency Response Program (CERP) spent very substantial sums of money, for example, US\$80 million in three quarters of 2005 , aimed at 'winning hearts and minds' (Karp 2006). Unfortunately, tactical considerations such as rewarding friendly individuals and groups, or the need to 'deliver development' drove such investment decisions. This was true at both the battalion as well at national levels. In the bargain, basic 'principles for assistance were set aside for military and political objectives, leading to nepotism and corruption as the Kabul Bank scandal illustrates' (Strand 2014). The ISAF and PRT approach, though called 'winning hearts and minds,' was a top-down process that did not address an imbalance between areas receiving lots of resources and others that received little or none. They also reflected 'quick fixes' that were less effective 
than longer-term development approaches. Ghani's position recognised that peacebuilding and state-building are intrinsically linked and must be internally driven.

Indian development partnership is highly valued in Afghanistan, even though the total amount committed and disbursed is miniscule compared with that of the traditional donors. This is because it is in response to felt demands articulated by the Afghan government and as response to them shows in line with the needs of the people, is value for money and appropriate to the local conditions. It compares very favourably with the performance of a donor like the United States (USAID, military, Department of Agriculture etc.), as detailed in Table 7.1 (compiled mainly from analysis in McCloskey et al. 2015).

Table 7.1 Appraisal of US aid to Afghanistan

'In just six years, the IG has tallied at least $\$ 17$ billion in questionable spending. This includes $\$ 3.6$ billion in outright waste, projects teetering on the brink of waste, or projects that can't-or won't - be sustained by the Afghans, as well as an additional \$13.5 billion that the average taxpayer might easily judge to be waste'

Afghanistan SIGAR has only examined a small percentage of the $\$ 110$ billion effort to rebuild and remodel

'Super colonial' attitude ... the American military dismissed a local NGO in Kunar as unimportant because it was 'just Afghans working there'

- $\$ 8.4$ billion was spent on counter-narcotics programmes that were so ineffective that Afghanistan has produced record levels of heroin-more than it did before the war started

- In 2008, the Pentagon bought 20 refurbished cargo planes for the Afghan Air Force at a cost of US\$486 million, but there were no spare parts and it was 'a death trap,' according to the Special Inspector General for Afghanistan Reconstruction. Sixteen of the planes were sold as scrap for the grand sum of $\$ 32,000$

- \$335 million power plant in Kabul, rush job, ended up \$181 million over budget, diesel-powered plant is so expensive to run (\$ 245 million per year), the Afghans are only using about $1 \%$ of its capacity, intermittent use is actually harming the equipment and putting it on the path to 'catastrophic failure'

- State Department spent \$106 million into refurbishing a compound in Mazar-e-Sharif to be a consulate but which cannot be used as it is deemed unsafe

- \$25 million blown on a fancy military headquarters nobody used

- $\$ 14.7$ million spent on a storage facility the military never used

- \$34.4 million programme to push Afghan farmers to produce soybeans. However, the crop doesn't grow well in northern Afghanistan and Afghans weren't particularly interested in eating it

- USAID spent nearly $\$ 8$ million on tree planting and sapling programme after being told by Afghan government and its own staff that it would fail 
Before concluding this section, it is important to point out that India's development partnership extends beyond funding and implementing projects in Afghanistan, and is guided by specific, regional factors, namely peace and stability in its neighbourhood. In the past, the development of jihadism as a strategic instrument to confront the Soviet occupation of Afghanistan had negative consequences for India once the Soviets went home. The jihadis were simply diverted to India, especially to Jammu \& Kashmir, which saw a raging insurgency that soon degenerated to terrorism. The collapse of the Afghan State allowed the sponsors of such jihadi groups to run training camps in Afghanistan for such groups, allowing them both the space to do so and the scope to deny any role in supporting terrorist groups. India simply cannot see a failed State in its neighbourhood or a State under the control of jihadi terrorists. India 'recognises that social and economic development of Afghanistan is vital to regional security' (Price 2013). Consequently, India was instrumental in pushing for Afghanistan's membership of the South Asian Association for Regional Cooperation (SAARC). Its membership was approved at the 13th SAARC summit in Dhaka (2005), and Afghanistan formally joined at the 14th Summit in New Delhi (2007) (Al-Madani 2005). The price India had to pay for this was the admission of China as Observer, along with Japan, the United States, South Korea and the European Union. This emphasis on regional cooperation has two implications. One is that India wants much greater economic ties between countries in the region, leading to mutual interdependence. Two, recognising that it is overwhelmingly the biggest economy in the region, India realises its responsibility to achieve this; hence India's active role in Afghanistan. As a result, the total value of trade between the two countries reached US\$280 million in 2010, from just US $\$ 80$ million in 2001. India 'represents Afghanistan's fifth largest source of imports, and India accounts for 20 per cent of total Afghan exports' (Al-Madani 2005).

As demonstration of India's motivations, at the '2012 Kabul 'Heart of Asia' conference, India offered to lead two confidence-building measures, intended to support Afghanistan and integrate it into the regional economy.' This included linking chambers of commerce, recognising that trade and investment was about private entrepreneurs taking the initiative. Within India there is confidence that it can 'take a lead in facilitating trade and commercial opportunities for Afghanistan and the region' (Sachdeva 2012). 
With this is mind, government of India facilitated the hosting of an Investment Summit on Afghanistan in New Delhi (June 2012). The Indian foreign minister highlighted certain emerging sectors as being potentially very productive, namely 'mining, infrastructure, telecommunications, agro-based and small-scale industries, health, pharmaceuticals, education and information technology' (Price 2013).

Development partnership and peacebuilding can never be divorced from politics, but to be sustainable must be mutually beneficial, which the India-Afghanistan partnership has shown to be. It would, therefore, be correct to say that 'India has been an important economic assistance partner for Afghanistan, and can help in other fields to prevent destabilization' (Ayres 2015).

\section{Afghan Perception of India’s Development PARTNERSHIP}

Discussions with a cross-section of decision makers, civil society representatives, strategic community in Kabul, Mazar-i-Sharif and Herat, surveys conducted from time to time by different agencies as well as articles in the Afghan media all lead to the unambiguous conclusion that India is the most liked country, that Indian projects are favourably looked upon and that these are seen as contributing to peace building since they meet the 'felt-needs' of the Afghan people and society. As a respondent commented-any project that contributes to upgrading the economy automatically contributes to peace building. He added 'Indian projects are unique and varied.' On peacebuilding, another respondent said that 'helping our economy and facilitating daily lives of the people through better roads, communications, the Salma Dam and humanitarian assistance has contributed to peace building in its own way.'

Specifically, responding to local pressure from the Herat region, the government of Afghanistan has renamed the Salma Dam as the IndiaAfghanistan Friendship Dam. This project is seen as hugely liberating western Afghanistan from dependence on foreign supply, will ensure reliable and consistent electric supply and has the potential to economically transform the region.

Similarly, the naming of one of the blocks of the new parliament building as Atal block in honour of former Indian prime minister is symbolic in a country where symbols are very important. A photo tweet showing the parliament building as India's gift and another photo showing the 
destroyed Dar-ul-Aman palace in Kabul as Pakistan's gift went viral in the Afghan social media. ${ }^{9}$ The present writer has worked in Afghanistan for years with the United Nations Assistance Mission (UNAMA), later as a consultant for UNDP, was frequently told by Afghans across the country and classes how they appreciate India's development assistance as it was primarily targeted at education, health and in establishing democratic institutions. And in responding to local needs. As former Deputy Minister of Energy Ahmad Wali Shairzay said 'The government wanted to import power, but they needed investment. That's when ADB and the Government of India came in' (Asian Development Bank 2009).

India is seen as a model partner in terms of dollar value and Indian projects were not seen as divisive. A respondent who has had a lot of experience dealing with donors compared NATO/ISAF assistance unfavourably with India's. According to him, the former constructed roads to meet their needs of supplies and to avoid attacks on their camps. He was particularly critical of their quick impact projects (QIPs) and CERP as these were tactically driven, including to be seen as 'rewarding' local commanders or strongmen, which has been divisive. Indian aid has not been divisive. Respondents reminded that Indian development partnership began in the 1950s, and post 2001, India is the largest regional development partner, by contrast China's support till date has been only US\$125 million. Many respondents pointed that India has not indicated any priorities and left it to the government. SDP was seen by a few who mentioned it as better than NSP, which was not sustainable. India's higher education scholarship was much appreciated since human development is an Afghan priority. One respondent was critical of the choice of subjects; according to him, Afghanistan needed graduates in mining, engineering, IT, MBBS, and not so many political scientists or sociologists. Capacity building, particularly in technical fields was seen to have benefitted from ITEC. Ministry of Energy and Water officials rating it very useful and pointed out that a number of their staff had gone to India for masters' degree. In the course of implementing NEPS, the Indian state-owned enterprise, Power Grid Corporation had trained their Afghan counterparts, which was much appreciated. And the government of India in the Salma Dam contract, has made the contractor responsible for running the plant for one year, handholding the take-over process so that at the end of the year, Afghan staff would be in a position to take over.

Regarding cooperation and coordination with international development partners, the Afghans pointed out that the WB and $\mathrm{ADB}$ route their 
support through the budget and there is good coordination. Regarding India and KFW (Germany), the support is off-budget but coordination is good. The USAID support is off-budget and the coordination is not so good. In the selection of projects, the European Union selects and implements on its own but they coordinate with the government. Branch offices of line ministries in provinces are involved. However, they operate in the safe areas in the north. WB and ADB support projects selected, and designed by the government. Both institutions fund such mutually agreed projects but monitor them rigorously. In the case of KFW, the government proposes but they have own priority; procurement is by them, but there is close coordination with the government. The government proposes projects to India, which then implements it.

Afghanistan has seen high, if fluctuating, growth rates since 2001. This has created jobs in the service sector. However, necessary skills are at a premium, so there are limitations to growth being driven by it. This is particularly so since external agencies and external financial support is being retrenched. Since literacy rates are still very low, only agriculture and related activities like food processing, dairy and so on can drive growth. A number of respondents suggested that India should step up its support for this sector. With China's recent decision to gift Afghanistan a few hundred tractors, one respondent wanted joint India-China support for agricultural development.

Many specifically referred to India as Afghanistan's 'best friend' and the general expectation of respondents that it should do more, specifically 'just keep helping us in every possible way.' Besides the general comments were some specific examples and suggestions that could be used both to influence India's approach to development assistance specifically as well help evolve global consensus on facilitating peacebuilding and State-building.

India's record in executing big projects, other than NEPS, was seen as something that needs improvement, even accounting for the insecure areas where Indian projects were (eastern Herat, Farah, etc.) and problems of transit through Pakistan. The reliance on Indian state-owned enterprises was identified as the reason for this unsatisfactory state of affairs. Lack of supervision and monitoring along with lack of discretionary decisionmaking with the Indian Embassy in Kabul were also issues, for example, once Delhi tightened the screws and accepted greater local discretion both the Salma dam and the parliament building project picked up momentum and finished far faster than what its progress till date had shown possible. 
The Indian performance in executing the difficult task of laying transmission towers over the Hindu Kush has been much appreciated by both Afghans and international partners. This was a technically complicated project, made more difficult by the fact that though it is an integrated one, its different components were executed by different agencies using different decision-making processes, different funding routes, different reporting norms, different monitoring and so on, and yet it worked well. And yet, other than NEPS and a few other projects, India prefers to act alone, and it simply refuses to pool money together with other donors. While it does extend budgetary support to Nepal and Bhutan, these are for historical reasons and an exception. This has two disadvantages that actually militate against India's approach to development partnership. One, it deprives countries like Afghanistan the benefit of large projects which require multi-donor support, particularly where Indian technology and approach would be most appropriate and cost-effective, for example, the Indian contractor who built the transmission line from the Uzbek border to Kabul could only come in because an Indian entity was tasked with part of the work. Absent the Indian presence, work funded by the other donors could conceivably have been executed but more expensively. Two, if more untied funds were extended to the Afghan government, it would be able to be seen as exercising more sovereign functions and also directly meet more of its citizens requirements. This point, however, cannot be over-stressed since India would not in the near future have the economic wherewithal to really contribute by way of 'cash' support.

The present writer can speak from personal experience that quite often India is seen as a role model in Afghanistan, both for firmly establishing democracy and for its economic achievements. As part of developing their national development strategy, the government and donors had jointly established broad sectoral consultative groups and narrower, subject-wise, working groups. Having attended many such meetings across sectors and subjects, the common feature that was clear was the desire to learn from India. The request would be to speak from the Indian experience, and not as a representative of the UN, as it was felt that such experience was more relevant to the local context. In a similar vein, the present writer underwent driving lessons in the United States with an Ethiopian lady as the instructor. She remembered and named her Indian school teachers (Mr Gupta and Mr Sharma) and said that her superior, another Ethiopian who was a senior academic in his country, also had Indian school teachers. A former Indian ambassador to Ethiopia mentioned that during the call 
on, the then President (Meles Zenawi) remembered his school teacher, an Indian named Mr Nair. There is a lesson in this for both India and for major donors. India effectively discontinued sending school teachers to developing countries, particularly low-income, and now restricts ITEC to technically qualified personnel. Similarly major donors could think in terms of collaborating with India to send such, relatively lower technically skilled personnel to low-income countries. This would be major costs savings with much better development outcomes. In Afghanistan, the USAID and a few others did use Indian training institutions for capacity building of Afghans for the same reasons, but this could be expanded.

Similarly, while supporting institution building, instead of trying to superimpose models of mature, high income democracies, donors could look at relevant experience from not just India, but Indonesia, Malaysia, Brazil, South Africa, Nigeria and so on. This would have greater resonance and lead to more sustainable outcomes. Development partnership should be more broad based to be effective.

This section cannot be complete without referring to an issue of major disappointment among many Afghan respondents, and that was in India's diffidence in supporting the Afghan national security forces (ANSF). A number of respondents expressed frustrations about India's refusal to step in a big way in supporting ANSF beyond a few training slots, and supply of relative less defensive equipment. ${ }^{10}$ There was visible disappointment that 'India's response to our request for supply of arms and equipment has not been what we expected' despite the fact that the 2011 IndiaAfghanistan Strategic Partnership does include security cooperation.' As a result, Afghanistan was 'forced to look elsewhere.' A number of respondents were emphatic that 'India must do much more in forcing Pakistan to curb down its terrorism ... India has a good dialogue with the United States and should use that opportunity to leverage the US to put pressure on Pakistan.' Another respondent was clear in his prescription that 'India should not look at Afghanistan through the prism of Pakistan.'

This is a subject where it would be difficult to find agreement. On the one hand, India was the earliest to point the finger at Pakistan for using terrorism as an instrument of State policy, well before the rest of the world would even consider it. Logically, as an Afghan respondent told us that since both India and Afghanistan have suffered from Pakistan-sponsored terrorism, India should more actively support Afghanistan's efforts to combat terrorism. On the other hand, there is the view that though India 'can do more, but New Delhi's concerns about poking a Pakistani 
hornets' nest have limited the security partnership' (Ayres 2015). The jury is still out whether India's more active security support to Afghanistan would have helped the process of stabilisation in that country, and the region, or made it worse.

Afghan interlocutors were also asked about their perception of China as a stakeholder in Afghanistan, and not just as a development partner. There was general acceptance that China was a powerful neighbour and had played an active role in training and arming the Mujahideen against the Soviets. They had established contacts with various leaders, groups, tribes and so on and these were kept alive even after the withdrawal of the Soviets.

China's principal interest in Afghanistan was perceived to prevent the destabilisation of Xinjiang province and that it would participate in economic reconstruction only where it advances its own economic interests. There was general agreement that China was not interested in domestic economic and social issues affecting the Afghans and would not mind Taliban coming to power or sharing power. And that it would stay away from direct military involvement. On Aynak where a Chinese firm won a global tender to develop the world's largest copper deposits, a respondent predicted that China would not begin work in Aynak Copper mines till 2019, and that 'nobody knows that they will do so even after that date.'

India's role in Afghanistan was seen as a security threat both by China and Pakistan. Respondents were in agreement that 'there is no comparison between the development assistance provided by India and China. Nobody would write about what happened to the various projects undertaken by China after 2002.' There was a specific reference to the highways built that were of poor quality and required resurfacing within no time. Consequently, the Chinese companies concerned had to leave because of widespread criticism. There was another reference to the hospitals in Kabul which were repaired and opened had to be closed the following day, due to the scale of construction defects. Not one patient was treated there. In support, the respondent gave a news item (Smith 2012). Afghans also mentioned that even Chinese brothels had to close down and that 'every Afghan knows about it and it was in the media too.'

A respondent was apprehensive that while China was powerful by itself but when combined with Pakistan, 'it was awesome and the Afghans know what it means to be at the receiving end of this combination.' Many suggested that both, China and Pakistan have been in touch with the 
Taliban-together as well as independently. It was stated that after the ouster of Taliban from Afghanistan, the Chinese met the Taliban in the gold mines being developed by China in Balochistan (they could not provide any specific details on this.) As regards arming the Taliban, they were emphatic in saying that the Chinese provided not just small arms but also HN-5 anti-aircraft missiles, mines, components for IEDs and how to fabricate them, and rocket-propelled grenades. As per the Afghans the Americans were aware of this and had even raised the issue with the Chinese. But when it came to arming the ANSF, the Chinese are hesitant to provide anything other than some token small arms.

\section{CONCLUSION}

India's emergence as a donor is yet to impact on the global development assistance framework and systems. However, India's impact in Afghanistan, and other neighbouring countries as well as the creeping presence in Africa can potentially lead to making the system more accountable and ensure more cost-effective delivery. At this moment of time, India and the traditional donors are on parallel tracks and as in monetary terms, India's contribution is miniscule even compared to China's, and it really does not matter. Fears about China's and India's takeover of Africa are grossly exaggerated in so far as India is concerned. Its present LOC exposure in Africa plus the targeted US\$10 billion over the next five years would still be under US\$18 billion. Its importance lies in its local impact that helps technologically upgrade the local industry and unleash agricultural potential, cost-effective and value for money. But in the larger interest of peacebuilding, both India and the traditional donors can learn from the other, and in some ways, seem to be doing so.

India has just overhauled its LOC guidelines, moving closer to the western model of development assistance but still respecting such partnership as being demand-driven. A number of weaknesses came up after a detailed review of past projects funded by LOCs (Mathew 2015)

- Weak project conceptualisation and lack of project synchronisation

- Change in scope and nature of LOCs by borrowing country

- Over-reliance by partner countries on a few Indian companies for project proposals and implementation

- Effects of political cycles/security issues and so on. 
The new approach provides for evaluation of long-term economic benefits, highest standards for ethics, Integrity Clauses in loan agreements, inspection of all documents, wide publicity of all procurement, system of pre-qualification of contractors/consultants, vetting of contract documents (milestone-linked payments, performance guarantee, retention money, penalty for delay, ethics and integrity clauses). Country classification would also follow IMF norms, and repayment schedules and element of concession have been further liberalised. Additionally, if there is a joint venture with an Indian entity, the borrowing country could use the concessional loan as its equity in the project, allowing both for Public Private Partnerships (PPPs) and large infrastructure projects. For African countries, the requirement to use Indian goods and services has been brought down to $60 \%$. However, there is no requirement to use anything but the borrowing countries' own systems, so respect for sovereignty remains.

The international community is also moving towards greater flexibility, value for money and respect for national systems. Following SEWA's successful skilling project for Afghan women, USAID gave it funds to run similar programmes for Afghan women, and USAID's use of Indian training institutions increased. Similarly, the WB has changed its conditionality on using its own procurement policy if it is satisfied that the borrower's processes are robust, for example, it has declared India's Power Grid as one such entity, so henceforth if Power Grid were to be the recipient of any WB loan, it can use its own processes.

The international community must also accept that India would primarily be involved in its own neighbourhood. In terms of LOCs, the order of exposure is Bangladesh, Sri Lanka, Nepal, Ethiopia, Mauritius, Myanmar, Sudan and Mozambique. The two largest single loans are to Bangladesh and Sri Lanka but since both are recent, and being transport focussed, have long gestation periods, disbursements are still relatively less. But India is sensitive to its neighbourhood and readily adopts flexible approaches, for example, 'in 2010, India extended a US\$ 1 billion LOC to Bangladesh for transport infrastructure, requiring that $85 \%$ of procurement of goods and services be from India. This was modified in 2012 , bringing down Indian content to $30 \%$. And US\$ 200 was converted into "non-conditional grant." Similarly it extends financial support to Sri Lanka, both for building 50,000 houses for IDPs affected by the civil war as well as for the rehabilitation/reconstruction of three main rail lines.

The way forward for India would be to increase its engagement with OECD's Development Assistance Committee (DAC). It does take part 
in some dialogue but not enough. It neither follows DAC's development assistance classifications nor does it report its assistance figures to DAC. It must give up its fears about being swamped by big, traditional donors and display greater confidence. India has much relevant experience to offer, and to learn. Similarly, the insular world of traditional donors must walk the talk on country ownership and demand-driven assistance. The road to effective peacebuilding would continue to challenge all involved and constant learning is the minimum required.

\section{Annex I: Illustrative List of Projects Funded by LetTers of Credit}

- Supply of railway locomotives and coaches to Angola-rail is a cheaper mode of transport than road, farmers are able to seek better markets, facilitated exploration of Kassinga Mines

- Supply of buses (single and double decker) to Bangladesh-improved public transport availability, eased traffic congestion and air pollution, generated employment for women and men

- Tractor assembly plant constructed in Benin, leading to increased supply of tractors-substantial improvement in cultivation of 40,000 hectares benefitting 1 million people

- Cement Plant constructed in Djibouti-reduced dependence on imports, but problems due to many partners

- Three sugar factories constructed in Ethiopia-delayed due to logistics but two running very well, third one still in problems due to complexity of operation including working with farmers

- Construction of national Assembly building in Gambia

- Tractor assembly line in Gambia-higher agricultural productivity

- Construction of cricket stadium in Guyana-needed for World Cup, foreign exchange earner

- Tractor assembly plant constructed in Mali-farm mechanisation has led to $30 \%$ increase in agricultural productivity, reduced dependence on imports for tractors

- High Voltage transmission line erected between Mali and Cote d'Ivoire-stable, affordable power supply to Mali

- IT Park in Mozambique-500 students trained, new ventures established by local entrepreneurs

- Manufacturing plant/assembly line for Tata Tractors in Myanmar 
- Constructed Nyabarongo Hydropower project in Rwanda-country's biggest, once fully commissioned, would supply $25 \%$ needs of country

- 350 public buses supplied to Senegal-as part of NEPAD

- Supply of water pumps to Senegal-country's irrigation cover has doubled, rice production up by $177 \%$

- Railway coaches and locomotives to Senegal-improved, and faster, public transport

- Improvement of railway infrastructure in Senegal

- Rehabilitation/reconstruction of three trunk rail lines in Sri Lankaimproved transport, peace dividend post-end of civil war

- Construction of Um Dabakir Power Plant $(4 \times 125 \mathrm{MW})$ in Sudan-will contribute to one-sixth of Sudan's total power demand

- Supply of police vehicles to Zambia-improved reach of police

- Supply of tractors to Tanzania-higher agricultural productivity and improved food security

- Assisted craft exchange programme with artists from India and Zimbabwe-knowledge sharing, adoption of better techniques, higher productivity

\section{AnNex II: India-Afghanistan Development PARTNERSHIP}

(List and figures taken from the Embassy of India website http://eoi.gov. in/kabul/?0707?000.)

Cumulative level of Indian assistance in Afghanistan amounts to US\$2 billion-a very significant amount for a developing country, largest for any neighbouring country, and the fifth largest bilateral donor.

It has been India's endeavour to act in conformity with the best aideffectiveness principles, taking fully into account the local government priorities, in coordination with other donors, using local sub-contractors and materials as far as practical, and with minuscule proportion of budget on security and salaries. These 'overhead costs' are significantly lower in case of Indian projects than in those undertaken by other donors.

Four areas of support.

- Large infrastructure projects

- Humanitarian assistance

- Capacity building initiatives, and

- 'Small Development projects' 
a. Large and medium infrastructure projects, for example

- Construction of a $218 \mathrm{~km}$ road from Zaranj to Delaram for facilitating movement of goods and services to the Iranian border (the project has been completed and handed over to Government of Afghanistan);

- Construction of $220 \mathrm{kV}$ DC transmission line from Pul-e-Khumri to Kabul and a 220/110/20 kV sub-station at Chimtala, completed and handed over; two more sub-stations are being constructed at Doshi and Charikar for which material, brought by air from New Delhi is being transported to the project sites.

- Construction of Salma Dam in Herat province (ongoing project, following approval of the revised project cost by the Cabinet in January 2013, work has resumed gradually from March 15.

- Construction of Afghan Parliament building.

- Setting up of five toilet-cum-public sanitation complexes in Kabul.

- Upgradation of telephone exchanges in 11 provinces (completed and handed over);

- Expansion of national TV network by providing an uplink from Kabul and downlinks in all 34 provincial capitals for greater integration of the country (completed and handed over).

The above list is not exhaustive.

b. Humanitarian Assistance, including the following:

- provision of free medical services and medicines through Indian Medical Missions (IMMs) located in Kabul and other cities of Afghanistan.

- Provision of food assistance of I million MT of wheat in the form of HEB distributed to approximately 2 million school children across Afghanistan, daily under a 'School Feeding Program' administered by the WFP.

- Assistance of 2.5 lakh MT of wheat to Afghanistan.

- Reconstruction and renovation of Indira Gandhi Institute of Child Health (IGICH) Gifting of ten ambulances. 
c. Capacity Building initiatives like:

- Reconstruction and renovation of the Habibia School in Kabul;

- Award of 500 ICCR long-term university scholarships (for undergraduate and post graduate degrees) and 500 short-term Indian Technical and Economic Cooperation (ITEC) vocational training slots for Afghan nationals annually from 2006 to 07 onwards (since 2009 , both ICCR and ITEC slots were increased to 675 annually and it has been decided to grant 1000 scholarships for Afghan Nationals (administered by ICCR) during the period 2012-13 to 2020-21.);

- Up to 258 Special Discretionary ITEC slots have been offered to Afghan Ministry officials for training programmes in India-over five such training programmes have been organised and the Ministry of Commerce and Industries, the Ministry of Agriculture and so on. have already had their personnel trained in various disciplines under this new scheme;

- Deputation of 30 Indian civil servants under UNDP's Capacity for Afghan Public Administration (CAP) programme; ongoing Indian contribution to UNDP's National Institution Building Program (NIBP) which finances attachment of Indian civil servants as Capacity Development Advisors (CDAs) in Afghan government institutionsthere are ten Indian CDAs currently working in various important Ministries of the Afghan Government;

- Signing of 'twinning agreements' between related Indian and Afghan Ministries;

- Setting up of an India-Afghan Vocational training centre for training 3000 Afghans in carpentry, plumbing, welding, masonry and tailoring;

- Project by Indian NGO SEWA for setting up Women's Vocational Training Centre in Bagh-e-Zanana (Kabul) for training 1000 women in garment making, nursery plantation, food processing and marketing.

- 614 Agriculture scholarships (BSc, Msc and PhD) have been made available to Afghan students under an Indian Council for Agriculture Research (ICAR)-administered scheme. Sixty Afghan agriculture students are presently studying in various Indian agriculture universities and more than 100 have been accepted for the academic year 2013-14. 
d. Small Development Projects, community-based, in vulnerable border areas, in the fields of agriculture, rural development, education, health, vocational training and so on. that can have direct and visible impact on community life, and with focus on local ownership and management. The Small Development Projects were implemented in two phases - the first in July 2006 comprising projects worth US\$11,216,179 and the second in June 2008 comprising projects worth US $\$ 8,579,537$. Sixty-five per cent of the projects are reported to be $100 \%$ complete. Some of them are awaiting final clearances of concerned authorities for completion certificate. Seventy-six projects have been completed, 34 projects are ongoing, 6 projects await tender finalisation with Afghan line Ministries, while ten projects await MEA approval. Till date, US\$13.135 million has been released to our Mission under phases I and II of Small Development Projects. The implementation of the projects is done entirely by Afghan government agencies (with advisory inputs from Indian Embassy), which helps in building local capacity towards project management. A MoU for implementation of the third phase of the SDP scheme was signed during President Karzai's visit in November 2012 with an additional provision of US\$100 million. Administrative and financial approvals for 60 projects, at an estimated cost of USD 14.223 million, under the third phase of the SDP scheme have been received from MEA in June 2013. The MoUs (in English and Dari) for each of these 60 projects have been finalised and waits signing. The third phase of SDPs is to be completed by $2015-16$.

The future contours of the Indian assistance programme in Afghanistan were illuminated during the visit of the Indian Prime Minister, Dr. Manmohan Singh, in May 2011. The PM had announced a further increase in India's aid commitment to Afghanistan by USD 500 million, thus raising the cumulative Indian commitment to US\$2 billion.

\section{NeW SCHEMES}

- Donation of 1000 buses for the Kabul and other municipalities with provision for maintenance support, training and infrastructure. Afghanistan has selected Delhi Integrated Multi-modal Transit System (DIMTS) as the Consultant to manage the process of pro- 
curing the buses and creating the structures for their maintenance and running. DIMTS has submitted a revised proposal.

- Donation of 500 tractors for Afghan farmers; provision of seeds and other assistance for the agricultural sector.

- Medical package consisting of the treatment of Afghan patients in select hospitals in India over the next three years to be implemented through the Afghan Ministry of Public Health;

- Rehabilitation and professional upgradation of the National Malaria and Leishmaniasis Centre of Afghanistan; and the

- Upgradation of the Indira Gandhi Institute of Child Health, including the neo-natal and maternal care unit.

- Setting up of a National Agricultural University.

- US\$50 million Buyers Credit Line to promote exports and attract Indian business to Afghanistan.

- Grant of US\$10 million for preservation and revival of Afghanistan's archaeological and cultural heritage and cultural exchanges.

- Grant of US\$4 million to the Government of Afghanistan for the restoration of the historic Stor Palace in Kabul.

- Assistance in setting up an Afghan National Institute of Mines. To begin with, the Government of India has offered training at ISM, Dhanbad, for up to 180 resource persons in the Ministry of Mines, Government of Afghanistan from April to December 2013. Training is to be imparted in 12 disciplines related to Mining for batches of 15 each. Five training modules (for $15 \times 2=30$ ) resource persons have been completed.

- Assistance in setting up of a computer laboratory at Habibia School.

- Supporting the second phase of the Confederation of Indian Industry (CII) Skills Development Program for providing vocational training to Afghan nationals.

- Establishment of a Jawaharlal Nehru Chair of Indian Studies at Kabul University

In pursuance of the decision of Prime Minister of India and President of the Islamic Republic of Afghanistan to support the ARCS to treat Afghan children suffering from CHD, Government of India has decided to grant financial assistance of US\$5 million to ARCS over a period of five years beginning 2015. Financial assistance provided by India will be utilised for the ongoing treatment by ARCS of Afghan Children at Artemis, Max and 
Fortis Hospitals in New Delhi. These hospitals have offered special concessional rates for treatment of these children. The first tranche of US\$ 1 million has already been disbursed to ARCS and additional disbursement would be made over the next four years.

\section{Annex III: List of Persons With Whom the Afghanistan-India Partnership was Discussed}

(Team consisting of Lt Gen PK Singh (Retd), Lt Gen PC Katoch (Retd), Maj Gen BK Sharma (Retd) and Mr Shakti Sinha at Herat, October 2/3, 2015; Kabul September 3/4 and November 21/22, 2015, and Mazar-eSharif, December 17/18, 2015)

1. Dr Rangin Dafdar Spanta, Chair AISS Advisory Board, former foreign minister, former NSA

2. Dr Sayeda Mojgan Mostavi, Deputy Minister of Publications, ministry of Information \& Culture

3. Dr Davood Moradian, Director, Afghan Institute of Strategic Studies

4. Azizullah Royesh, educational consultant, Marefat Civil Capacity Building Organisation

5. Habibullah Fouzi, Member, International Relations Committee, High Peace Council

6. Shahmahmood Miakhel, Country Director, United States Institute of Peace

7. Abbas Noyan, general secretary, Rights and Justice Party

8. M. Ashraf Haidari, Research Fellow, AISS/Director of Policy \& Strategy, Ministry of Foreign Affairs (MOFA)

9. Eng Sebghatullah Tamim, Excellent Planning \& Construction Company

10. Ahmed Saeedi, political expert, civil society

11. Lt Gen Abdul Hadi Khalid, former Deputy Minister of the Interior

12. Dr Moheb Spinghar, Director General, Institute for Diplomacy, MOFA

13. Mr Mohammad Ismail Rahimi, Deputy minister, Ministry of Economy

14. Ehsanullah Zaki, Chief of Staff to First Vice President, former MP and Jumbish party activist 
15. Wahidullah Shahrani, former minister of mines, former commerce minister and opposition politician

16. Eng Kohistani, acting Deputy minister/DG, Ministry of Energy \& water

17. Eng Osmani, Minister of Energy \& water

18. Mr Murad, Minister of Economy

19. Mustafa Aria, Director, Aid Coordination, Ministry of Finance

20. Amrullah Saleh, former Director NDS and opposition politician

21. Mohammad Naeem Aubzada, Director, TEFA, Kabul

22. Ahmad Sulaiman Aslam, Ministry of Finance

23. Feridudin Ilham, Deputy Head of Public Relations and Outreach

24. Humayun Khairi, Office of First Vice President

25. Maj Gen Masood Ahmad Azizi, Deputy Minister of the Interior

26. Mrs Homayra Etemadi, Deputy Chief of Staff under President Karzai

27. Abdul Jabbar Ariyaee, Senior Advisor, Ministry of Education

28. Mrs Nasrine Abou Baker, Office of CEO

29. Dr Mirwais Balkhi, Centre of Strategic Studies

30. Prof Rafiullah Niazi, Director, Academy of Science

31. Hashem Rasouli, The Voice of Afghanistan

Plus many members of the media, think tank researchers, senior officials in ministries of economy, energy and water, agriculture, finance, independent directorate of local governance, independent administrative reforms and civil service commission, Ambassador of India and his staff.

\section{Notes}

1. This section (India as donor) draws heavily on Rani D. Mullen, 'India's Development Assistance: Will it Change the Global Development Finance Paradigm?' Prepared for the Workshop on Innovation in Governance of Development Finance: Causes, Consequences os the Role of Law Conference April 8-9, 2013, Gießen \& New York University School of Law. Can be accessed at http://www.iilj.org/newsandevents/documents/mullen.pdf And Lt Gen PK Singh, above cited.

2. Mullen, op cit.

3. Mullen estimates that a thousand dollars would easily allow for a person's three weeks' training in India.

4. This has allowed India to expand its development partnership portfolio considerably without a concomitant charge on its budget, with govern- 
ment's own commitment limited to the interest subvention charges. Exim Bank raises its capital from international bond markets since it needs hard currency for its borrowers.

5. Information from compilation by IDRC, found in Mullen, op. cit., based on Government of India Budget, Grants \& Loans to Foreign Governments, Statement 11 of the Expenditure Budget, Ministry of External Affairs, Government of India.

6. Mullen, op cit.

7. Discussions with senior officials at the Ministry of Energy and Water, Government of Afghanistan, November 21, 2015.

8. Extensive discussions were held with the officials of the Ministry of Economy, Kabul and with concerned Embassy staff, September third and November 21, 2015.

9. Cell phone coverage in Afghanistan is over $60 \%$ of the population.

10. These discussions were before the December 2015 supply of the four promised helicopter gunships (Mi 25).

11. Mullen, op cit.

\section{REFERENCES}

Al-Madani, Abdulla. 2005. Implications of Afghanistan's Inclusion in SAARC. Middle East Transparent. http://www.metransparent.com/old/texts/abdullah_ elmadani/abdullah_elmadani_implications_of_afghanistan_inclusion_in_saarc. htm

Arora, Kashyap, and Rani Mullen. 2017. India's Development Cooperation with Bangladesh: Lines of Credit (LOCs). Indian Development Cooperation Research Blog. http://cprindia.org/sites/default/files/op-eds/India\%E2\%80\%99s\%20 development $\% 20$ cooperation $\% 2$ with $\% 20$ Bangladesh $\% 20$ Lines $\% 20$ of $\% 20$ credit $\% 20 \% 28$ LOCs $\% 29 \% 20 \% 281 \% 29$.pdf

Asian Development Bank. 2009. Energy is Life: Bringing Power to Afghanistan. https://www.adb.org/sites/default/files/publication/29647/energy-life.pdf

Ayres, Alyssa. 2015. Why the United States Should Work With India to Stabilize Afghanistan. Council on Foreign Relations. http://www.cfr.org/afghanistan/ why-united-states-should-work-india-stabilize-afghanistan/p364l4

Chanana, Dweep. 2009. India as an Emerging Donor. Economic and Political Weekly 44 (12): 11-14. http://www.epw.in/journal/2009/12/commentary/ india-emerging-donor.html

Department for International Development (DFID). 2010. Building Peaceful States and Societies: A DFID Practice Paper. London: .DFID. https://www. gov.uk/government/uploads/system/uploads/attachment_data/ file/67694/Building-peaceful-states-and-societies.pdf 
Dornsife, Cinnamon. 2013. BRICS Countries Emerging as Major Aid Donors. Asia Pathways. http://www.asiapathways-adbi.org/2013/10/brics-countriesemerging-as-major-aid-donors/\#sthash.sZgEOgAi.dpuf

Gupta, Swati. 2015. 4 Things to Know about India's Summit with African Leaders. Time. http://time.com/4093951/india-africa-summit-diplomacytakeaways /

Haidari, Ashraf. 2015. India and Afghanistan: A Growing Partnership. The Diplomat. http://thediplomat.com/2015/09/india-and-afghanistan-a-growingpartnership/

Indian Technical and Economic Cooperation Program. 2013. About ITEC. https://www.itecgoi.in/about.php

International Commission for Red Cross (ICRC). 2014. From Aid to Partnerships: India's Humanitarian Assistance. https://www.icrc.org/en/document/aidpartnerships-indias-humanitarian-assistance

Karp, Candace. 2006. Leading by Example: Australia's Reconstruction Task Force and the NGO Civil-Military Relationship in Afghanistan. Security Challenges 2 (3): 1-8. http://www.regionalsecurity.org.au/Resources/Files/vol2no3Karp.pdf

Mathew, Joe E. 2015. Exim Bank extends 200th Line of Credit to Finance Exports to Developing Countries. Business Today. http://www.businesstoday.in/ sectors/banks/exim-bank-extends-200th-line-of-credit-to-finance-exportsto-developing-countries/story/224186.html

McCloskey, Megan, Tobin Asher, Lena Groeger, and Sisi Wei. 2015. Behold: How the US Blew $\$ 17$ Billion in Afghanistan. Public Radio International (PRI). http://www.pri.org/stories/2015-12-18/behold-american-taxpayerwhat-happened-nearly-half-billion-your-dollars

Ministry of External Affairs Report. 2012. India and Afghanistan: A Development Partnership. Accessed March 1, 2013. http://www.mea.gov.in/Uploads/ PublicationDocs/176_india-and-afghanistan-adevelopment-partnership.pdf

Mullen, Rani D. 2013. India-Afghanistan Partnership. Indian Development Cooperation Program, Centre for Policy Research. http://cprindia.org/sites / default/files/policy-briefs/India-afganistan\%20brief_0.pdf

Organization for Economic Co-operation and Development (OECD). 2012. Development: Aid to Developing Countries Falls Because of Global Recession. http://www.oecd.org/newsroom/developmentaidtodevelopingcountries fallsbecauseofglobalrecession.htm

Pan-African e-Network. 2016. Pan-African e-Network Project. http://www.pan africanenetwork.com/

Price, Gareth. 2013. India's Policy towards Afghanistan. Chatham House 2013/04. https://www.chathamhouse.org/sites /files/chathamhouse/public/ Research/Asia/0813pp_indiaafghanistan.pdf

Ramachandran, Vijaya. 2010. India Emerges as an Aid Donor. Centre for Global Development. http://www.cgdev.org/blog/india-emerges-aid-donor 
Roopanaraine, Les. 2013. China: 'Rogue' Donor or Beacon of South-South Cooperation. The Guardian. http://www.theguardian.com/global-developmentprofessionals-network/2013/apr/02/china-aid-africa-development

Sachdeva, Gulshan. 2012. The Delhi Investment Summit on Afghanistan. Institute for Defence Studies and Analyses. http://www.idsa.in/idsacomments/The DelhiInvestmentSummitonAfghanistan_gsachdeva_260612

Smith, Bernard. 2012. Afghan Hospital in Coma for Poor Workmanship. Aljazeera. http://www.aljazeera.com/indepth/features/2012/10/201210210243520232. html

Strand, Arne. 2014. Maintaining Development Momentum or Just Providing Aid. ISPI Analysis 261. https://www.cmi.no/publications/file/5194-http-wwwispionline-it-sites-default-files-pubbl.pdf

Shakti Sinha is Director, Nehru Memorial Museum and Library, New Delhi.

Open Access This chapter is licensed under the terms of the Creative Commons Attribution 4.0 International License (http://creativecommons.org/licenses/ by $/ 4.0 /)$, which permits use, sharing, adaptation, distribution and reproduction in any medium or format, as long as you give appropriate credit to the original author(s) and the source, provide a link to the Creative Commons license and indicate if changes were made.

The images or other third party material in this chapter are included in the chapter's Creative Commons license, unless indicated otherwise in a credit line to the material. If material is not included in the chapter's Creative Commons license and your intended use is not permitted by statutory regulation or exceeds the permitted use, you will need to obtain permission directly from the copyright holder.

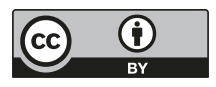

